\title{
Identification of Sustainable Option in Water Conservation for Rural India
}

\author{
Vidula Arun Swami ${ }^{1 *}$, Sushma Shekhar Kulkarni ${ }^{2}$, Akshay Rajan Thorvat ${ }^{3}$, Sheetal Satyaveer Varur ${ }^{1}$ \\ ${ }^{1}$ Civil Engineering Department, Kolhapur Institute of Technology, Kolhapur, INDIA \\ ${ }^{2}$ Rajarambapu Institute of Technology, Sakbarale, Sangli, INDIA \\ ${ }^{3}$ Environmental Engineering Department, Kolhapur Institute of Technology, Kolhapur, INDIA
}

*Corresponding Author: vidulaswami@gmail.com

Citation: Swami, V. A., Kulkarni, S. S., Thorvat, A. R. and Varur, S. S. (2018). Identification of Sustainable Option in Water Conservation for Rural India. Aquademia: Water, Environment and Technology, 2(1), 03. https:// doi.org/10.20897/awet/86714

Published: April 10, 2018

\begin{abstract}
India is a country of villages with $68.84 \%$ of the total population living in rural areas. The villagers are lagging in their developments due to the scarcity of water. Hence in this study, it was decided to find out the technique of water conservation which will sustain in rural areas and to compile the results by applying the model which will work for this. Considering the topographical features of a small plot of area two hectares of Kaneri watershed situated in Kolhapur District, Maharashtra, the structures for water conservation had been implemented in it in June 2011. The structures included gully plugs on existing water stream followed by the farm pond at its end along with farm terraces and continuous contour trenches surrounding the water stream. The practical evidence proved the positive impact of water conservation structures on water conservation and groundwater recharge. For assessing this impact technically for ungauged Kaneri watershed, SWAT (Soil and Water Assessment Tool) Model was used in the study and both the results were compiled. From the model results, the sediment yield and water yield showed expected impact on the watershed. Thus, the SWAT model proved to be an effective tool in assessing the impact of changes in land management on runoff and sediment yield.
\end{abstract}

Keywords: farm pond, water conservation, SWAT model, sediment yield, runoff

\section{INTRODUCTION}

Substantial variations in the quantity, incidence and duration of rainfall in individual tracts of India from year to year make watershed management of supreme necessity in the country, which when implemented, adds one drop in substantial water supply and at the same time subtracts the same drop from the potential flood, thus giving twofold benefit to the community. The economical development and management of villages in India is one of the most important factors for the growth of Indian economy. India is the agriculture based country. Agriculture contributes one fifth of the gross domestic product in India. (Kumbhar et al., 2013). Watershed management tries to bring about the best possible balance in between the water resources on one side and human and other living beings on the other, improving the socio-economic status of the villagers (Naik, 2009). Some initiatives in India have grappled successfully with this complex process, and different models of people driven development have emerged. Perhaps the most notable of these is the remarkable work of Mr. Annasaheb Hazare in Ralegan Siddhi village (Mishra, 1996). To deal with water management issues, one must analyze and quantify the different elements of hydrologic processes taking place within the area of interest. To achieve this goal the choice and use of an appropriate watershed model is a must (Sathian and Shyamala, 2009.) 
Ralegan Siddhi and Hivre Bazaar are the best examples of sustainable development with poverty reduction. Various rainwater harvesting structures like check dams, farm ponds, harvesting bunds, percolation tanks etc. proved effective in different regions of India as well as Maharashtra. Women's participation in the formation of self-help groups and motivation to youth for active participation in the process resulted in speeding up of the process. The areal extent of cultivable land changed from 250 acres in 1975 to 1750 acres, making the villagers self-sustained in crop and milk production (Self-visit to Ralegan Siddhi on 7-12-2008). The program's early and biggest success is Hiware Bazaar, a village located in the rain-shed area of Ahmednagar district in India, the same district as Ralegan. (Mehta and Tripathi, 2008)

According to the World Bank Report, India will be water stressed in the year 2025 and water scarce by 2050. Only 0.1-hectare per capita land will be available by the end of 2025. BAIF (Bharat Agro Industries Foundation) Development Research Foundation, Pune launched its integrated watershed development Program in various parts of the country in 1990 and implemented it in about 262 villages and got the outcomes like an increase in surface and groundwater availability, increase in second crop area by $20-25 \%$ over the baseline situation. A network of farm pond along with gulley plugs on small gullies and rainwater harvesting structures in Hassan district of Karnataka state yielded very nice results. (Kakade, 2012). The watershed interventions in Kothapally villageresulted in higher infiltrability and water holding capacity of the soil, as well as increased ground water level, due to which in dry spells of monsoon water became available and soil loss decreased ten times. Thus integrated watershed management in Kothapally, built resilience in agriculture systems and improved livelihood of the farmers. (Garg and Wani, 2011).

Farm ponds have a significant role in rain fed regions with annual rainfall more than or equal to $500 \mathrm{~mm}$. For average annual rainfall (AAR) between 500 to $750 \mathrm{~mm}$, the farm ponds with capacity of 250 to $500 \mathrm{~m}^{3}$ can be constructed. If AAR is more than $750 \mathrm{~mm}$ the farm ponds without lining, with capacity more than $500 \mathrm{~m}^{3} \mathrm{can}$ be constructed particularly in black cotton soil regions. It was observed from field experience that at least two to three rainfall events can occur, making the ponds highly beneficial to farmers. (Reddy et al., 2012). Amongst several interventions of Integrated Watershed Management Programmes (IWMP) farm pond is the most important and promising technology with other environmental benefits. About 853 hectares area of Shivaji University Campus, Kolhapur district, Maharashtra, India has been surveyed and depending on its geology, topography, and soil, a pond of capacity 8.52 million cubic feet, along with continuous contour trenches, check dam and nallah bunding on about 51 hectares area have been constructed. For last three years, the University has become self-sustained in water requirements for the whole campus. Three more water tanks have been proposed in the campus for recharging groundwater. (Ingavale et al., 2013). It was assessed that the percolation pond has increased the water availability by about three times as compared to the situation without pond. In order to assess the quantity of recharge in the percolation pond, a lumped model analysis is carried out. (Jothiprakash et al., 1997).

SWAT allows the user to delineate the watershed and sub-basins using DEM. Once the loadings of water, sediment, nutrients, and pesticides from the land phase to the main channel have been determined, the loadings are routed through the streams and reservoirs within the watershed. The water balance for reservoirs includes inflow, outflow, rainfall on the surface, evaporation, seepage from the reservoir bottom, and diversions. (Moriasi et al., 2012). By far, the most widely used statistics reported for calibration and validation are $r 2$ and NSE. The $\mathrm{r}^{2}$ statistic can range from 0 to 1 , where 0 indicates no correlation and 1 represents perfect correlation, and it provides an estimate of how well the variance of observed values are replicated by the model predictions (Krause et al., 2005). Calibration on Cisadane Catchment Area hydrology model was done during 2007, and then validation was done for 2009 period. Manual calibration of several parameters resulted in correlation error $\left(\mathrm{R}^{2}\right)$ of 0.708 and NSE 0.71 , and $\mathrm{R}^{2}$ and NSE values were 0.709 and 0.72 , respectively for validation model. (Ridwansyah et al., 2014)

\section{MATERIALS AND METHODS}

The present study was done in a small village, Kaneri, $11 \mathrm{~km}$. South East of Kolhapur, Maharashtra (at 16.6055 and $16.6412 \mathrm{~N}$ and 74.2535 and $74.2906 \mathrm{E}$ ). Collection of primary data in pilot plot study was done by observation and discussion with local people, through questionnaires, through social mapping, and by technical surveys. Collection of secondary data had been achieved through census records, preparation of maps by satellite data and website data. The geospatial technology i.e. GIS tool was used for data analysis and for water and sediment yield assessment a hydrological simulation model i.e. SWAT model was used.

\section{Pilot Plot Study}

For evaluating the impact of watershed management techniques on the economic status of the people, pilot plots were selected where best possible management practices have been implemented. Considering the 
Table 1. Location details of the sites selected for Pilot study

\begin{tabular}{lllcc}
\hline Sr.No. & Plot No.\& Location & Proposed Structures & Longitude & Latitude \\
\hline 1 & 1 (Subwatershed No.28) & Farm Pond & 74.2848 & 16.6110 \\
\hline 2 & 1 (Subwatershed No.28) & CCT 1 & 74.2850 & 16.6105 \\
\hline 3 & 1 (Subwatershed No.28) & CCT 2 & 74.2849 & 16.6105 \\
\hline 4 & 1 (Subwatershed No.28) & CCT 3 & 74.2846 & 16.6105 \\
\hline 5 & 1 (Subwatershed No.28) & Gulley Plug 1 & 74.2854 & 16.6104 \\
\hline 6 & 1 (Subwatershed No.28) & Gulley Plug 2 & 74.2852 & 16.6105 \\
\hline 7 & 2 (Subwatershed No.1) & Farm Pond & 74.2761 & 16.6360 \\
\hline 8 & 2 (Subwatershed No.1) & Bore well recharging pit & 74.2762 & 16.6359 \\
\hline
\end{tabular}

\section{KANERI WATERSHED STRUCTURES}
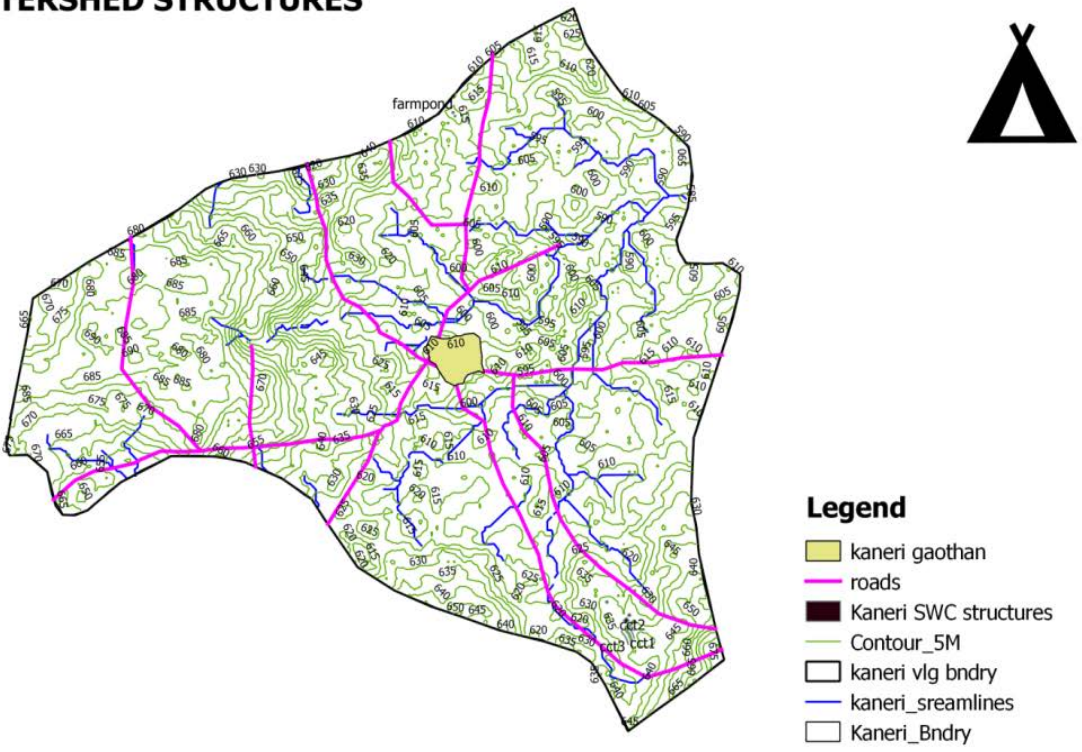

0.005

0

0.005

0.01

0.015

$0.02 \mathrm{~m}$

Figure 1. Watershed management plan for pilot plots

topography, land use, geological conditions, willingness of farmer to construct recharge structures, ground slope, soil texture, and properties two sites owned by two farmers in Kaneri watershed were selected.

Plot 1 was provided with the structures needed for soil and water conservation. Figure 1 shows the map with the watershed structures implemented in the watershed in two different plots. Plot 1 was used for analysis for prediction of water storage due to the construction of suitable rainwater harvesting structures. Plot 2 was not used for analysis due to non-availability of the data after the construction of the structures there. The plots along with the structures were overlaid on the geo-referenced map of Kaneri and the map was produced. Figure 1 gives the geo-referenced watershed plan for Kaneri watershed.

\section{Creation of Database}

To delineate the watershed and sub-basins and to determine drainage networks SWAT uses the digital representation of the topographic surface. DEM is the digital representation of the topographic surface. A $30 \mathrm{~m} \mathrm{x}$ $30 \mathrm{~m}$ resolution ASTER-DEM was derived and re-sampled to $15 \mathrm{~m} \mathrm{x} 15 \mathrm{~m}$ for ease in data acquisition. A land use map was created by recording the crop type on each plot in the watershed and by identifying the land cover on areas other than cultivated fields. LULC map was acquired from LISS III (Linear Imaging and Self Scanning Sensors). The digital Google image was geo-referenced by taking control points around and inside the watershed. The shape file representing each plot and other land covers was created using the digitizing tools provided in ArcGIS, ArcMap. The soil map obtained from the NBSS \& LUP was geometrically registered to the base data to match Landsat \& IRS satellite imageries. The geo-referenced soil map was used to assist in the visual classification 
of satellite imagery for obtaining soil categories. The final vector map was stored in a geo database which is amenable to spatial analysis.

Multiple Gauges were used for weather data input. The main inputs used for weather data in the model are gridded rainfall and temperature. The curve number method (USDA-SCS, 1986) was chosen for calculating runoff. Penman-Monteith method (Monteith, 1965) was chosen for calculating potential evapo-transpiration. The variable storage method was chosen as the channel routing mechanism with the assumption that channel dimensions remain constant. The model was set to run from 1 January 1979 to 31 July 2014 with a monthly printout interval. By considering the drainage lines the stream network was prepared. The watershed outlet was manually added and selected for finalizing the watershed delineation. With this information, the model automatically delineated a watershed of 535.48 ha and 28 sub-basins were produced.

\section{Model Setup}

Drainage network was prepared which was useful for delineation. The delineated watershed and the prepared land use map overlapped by $100 \%$. While running the model, land use land cover map, soil map, slope map and weather data were provided as an input on which the processing was done through SWAT model. Modeling process once over gave the output in the form of surface runoff, PET (Potential Evapotranspiration), Evapotranspiration, Percolation, Groundwater flow, Soil Moisture, Water Yield and Sediment Yield. The estimated runoff and sediment yield from each sub-watershed were compared with measured values and the effect of LU/LC, soil, and topographic characteristics were then evaluated (Mishra, 1996). Multiple HRUs were defined within a sub-basin by ignoring land uses less than $2 \%$ of the sub-basin and ignoring soil types in a sub basin covering less than $5 \%$ of the sub basin. A total of 76 HRUs for 28 sub basins were created.

\section{Performance Evaluation of the Model}

In the present study, for calibration and validation, conventional method along Arc SWAT tool was used. The main function of an interface is to provide a link between the input/output of a calibration program and the model. The simplest way of handling the file exchange is through text file formats. The model was run for thirty-six years from 1979 to 2014. Surface runoff and sediment calibration for the Kaneri watershed was conducted for the years from 1979 to 2000 . Also the surface runoff and sediment validation for the Kaneri watershed was carried out for the years 2001 to 2013.

Calibration and validation of SWAT model for daily surface runoff performed well with coefficient of determination $\left(\mathrm{R}^{2}\right)$ of 0.686 and Nash-Sutcliffe Efficiency coefficient (NSE) of 0.686 for the calibration period 2012 and with $\mathrm{R}^{2}$ of 0.863 and NSE 0.863 for the validation period 2013. The model also performed well in simulating sediment yield on daily basis with the coefficient of determination $\left(\mathrm{R}^{2}\right)$ of 0.729 and NSE of 0.729 for the calibration period and with $\mathrm{R}^{2}$ of 0.945 and NSE of 0.945 for the validation period. Similarly model performed well on monthly basis for surface runoff with coefficient of determination $\left(\mathrm{R}^{2}\right)$ of 0.768 and Nash-Sutcliffe Efficiency coefficient (NSE) of 0.30 for the calibration period 2012 and with $\mathrm{R}^{2}$ of 0.720 and NSE 0.703 for the validation period 2013. The model showed satisfactory results in simulating sediment yield on monthly basis with the coefficient of determination $\left(\mathrm{R}^{2}\right)$ of 0.971 and NSE of 0.765 for the calibration period and with $\mathrm{R}^{2}$ of 0.982 and NSE of 0.981 for the validation period.

\section{FARM POND: CONSTRUCTION DETAILS AND ESTIMATE}

A farm pond is usually of $3 \mathrm{~m}$ depth with width and length varying depending upon the farmer's land and catchment water potential in his field. Some farm ponds are without any permanent base or side linings. These can recharge groundwater as water percolates down in unlined ponds and help in raising water tables in nearby wells. Figures 2 and 3 show the Plan and Section of Farm Pond (Das, 2004).

The total cost of the farm pond in Rupees is 32200.00 (Ref. DSSR 2012, Government of Maharashtra for rates). Maharashtra took up promotion of farm ponds in a massive way in the first year of RKVY (Rashtriy Krishi Vikas Yojana) itself. A project of Rs. 92.74 crores were approved for farm ponds as the first project of RKVY in 2007-08. This program has helped in providing protective irrigation for about 81,145 ha during Kharif (Department of Agriculture, Maharashtra, 2012). Table 2 gives a detailed estimate of a farm pond. 


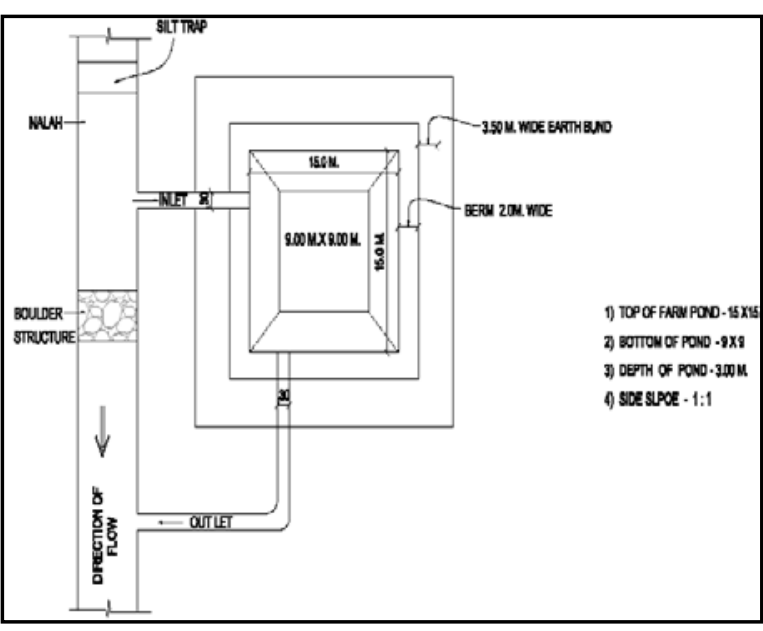

Figure 2. Plan of Farm Pond

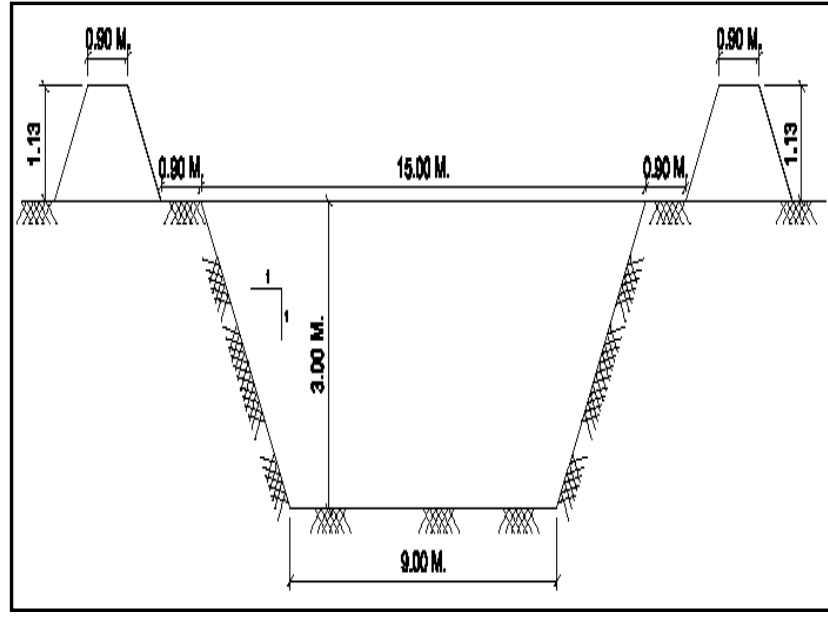

Figure 3. Section of farm Pond

Table 2. Estimate of farm pond (Santosh, 2011)

\begin{tabular}{|c|c|c|c|c|}
\hline Sr. no & Particulars & Quantity & Rate in rupees & $\begin{array}{r}\text { Amount in } \\
\text { rupees }\end{array}$ \\
\hline 1 & Marking of the site as per drawing and as directed by engineer in charge. & Lumpsum & 500.00 & 500.00 \\
\hline 2 & $\begin{array}{l}\text { Excavation in hard soil, dry or moist including dressing and disposal of } \\
\text { excavated material along the sides of cutting to side slope1:1 including } \\
\text { compaction etc. complete. For surplus material lead upto } 30.0 \mathrm{~m} \text { and lift upto } \\
3.0 \mathrm{~m} \text { as directed by engineer in charge. }\end{array}$ & $465.0 \mathrm{cum}$ & 60.00 & 27900.00 \\
\hline$\overline{3}$ & $\begin{array}{l}\text { Construction of boulder structure to slope } 1: 1 \text { by using available stones at site } \\
\text { as directed by engineer in charge including lead upto } 30.0 \mathrm{~m} \text { etc. complete }\end{array}$ & 10.0 cum & 300.00 & 3000.00 \\
\hline \multirow[t]{2}{*}{4} & Sowing grass seeds as directed by in charge & $2.0 \mathrm{~kg}$ & 400.00 & 800.00 \\
\hline & Total & & & 32200.00 \\
\hline
\end{tabular}

\section{Pilot Plot Experimentation}

\section{Total Water Recharged by Constructed Structures (An Experimental Analysis for Plot 1)}

Total rainfall in Kaneri village since June start to 12 August $2012=51 \mathrm{~cm}$.

a) The water recharged by farm pond

Water recharge $=[(15 \times 15)+(9 \times 9)] /(2 \times 3)=459.00 \mathrm{cum}$.

It is assumed to be recharged minimum 4 times in monsoon:

Water recharge $=4 \times 459.00 \mathrm{cum}=1836.00 \mathrm{cum}$

b) The water recharged by Contour trenching

Water recharge $=3437.23 \mathrm{cum} /$ acre $\times 60 \%=2062.33 \mathrm{cum}$

But, actual water available in the watershed

Water recharge $=4000 \times 0.51 \mathrm{~m}$ (up to 12 August 2012) $=2040 \mathrm{cum}$

Therefore, actual recharge due to contour trenching is

Water recharge $=2040 \times 60 \%=1224 \mathrm{cum}$

Hence, the total water recharge $=\mathrm{a}+\mathrm{b}=1836+1224=3060$ cum

Thus, water recharged in pilot watershed plot of 2 ha area due to constructed structures was predicted to be minimum 3060 cum per year.

\section{Cost and Water Recharge due to Watershed Management Structures in Pilot Plot}

The structures were constructed in the pilot plot according to the site conditions there. The area is hilly with flat terrain at the foothill. The topography resulted in a large amount of soil loss every year. By discussion with the plot owner and studying the topography of the area, the recharge structures appropriate for the area were finalized. These were the farm pond of size $15 \mathrm{~m} \times 5 \mathrm{~m}$ at the top with $9 \mathrm{~m} \times 9 \mathrm{~m}$ at bottom with $3 \mathrm{~m}$ height, gully plugs 2 in number at $12 \mathrm{~m}$ interval on the existing stream on the upstream side of the farm pond, three continuous contour trenches (CCT) of $15 \mathrm{~m}$ length at $10 \mathrm{~m}$ interval on the sloping ground. The construction was done with the local labor under the supervision of the plot owner. The farm pond was excavated with the help of JCB owned by the local person, resulting in reducing the total cost of the overall construction. The details of the cost of the construction of the structures have been given in Table 3 . 
Table 3. Total cost of the structures constructed in Plot 1

\begin{tabular}{lcc}
\hline Recharge Structures & Water Recharged & Cost of Construction \\
\hline Farm Pond $(15 \mathrm{~m} \times 15 \mathrm{~m} \times 3 \mathrm{~m})$ & $1836 \mathrm{cum}$. & \\
\hline Contour Trenching & $1224 \mathrm{cum}$. & Rs. 35,000 \\
\hline Gully Plug and Earthen Bunds & $3060 \mathrm{cum}$. & \\
\hline Total Recharge of Water & & \\
\hline
\end{tabular}

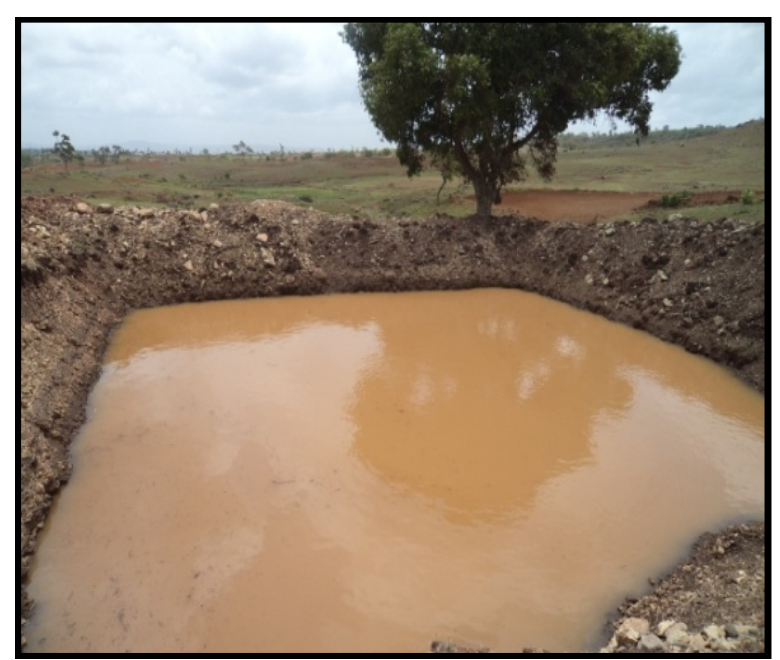

Figure 4. Farm pond immediately after construction

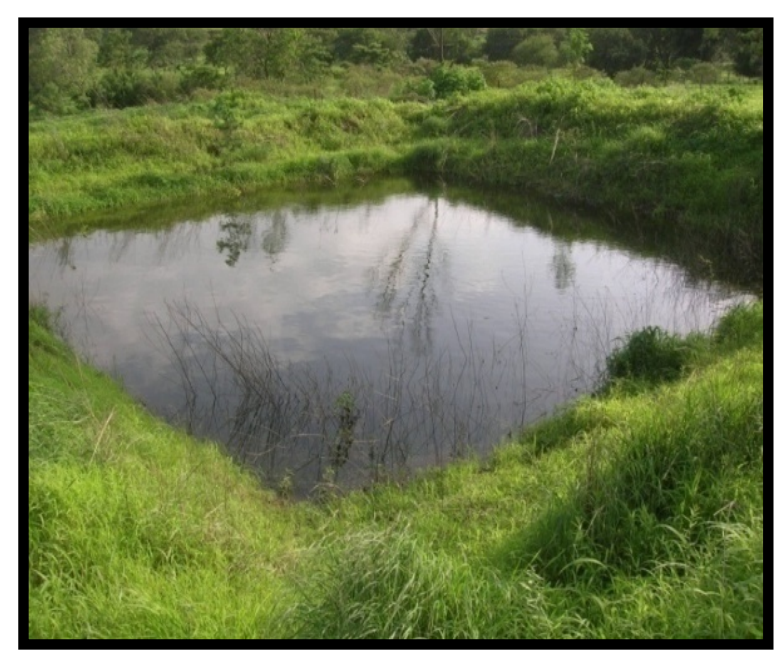

Figure 5. Farm pond at end of monsoon

\section{Soil Erosion Check due to Watershed Management Techniques}

During the visit to experimental plot area before the end of our study, in May 2011, lots of soil erosion was found. There was no any check to the runoff through the terrain. Even grass was unable to grow. The sites remained idle for so many years. Due to the continuous erosive action of water, the land was changed into barren land. The farm pond was constructed on downstream of the stream so that it could get filled by water resulting in preventing the erosive action of water. On the upstream side of the farm pond, two gully plugs were constructed at the interval of 10-12 m., using locally available stones to reduce soil erosion. On sloping land of the slope, $1 \%$ to $2 \%$ three contour trenches were excavated which could help to stop the erosion of soil. It resulted in the growth of grass in the immediate monsoon. It also resulted in maintaining soil moisture content. The field owners could have cultivation in the larger area of the sites due to the availability of irrigation water and soil moisture throughout the Kharif season.

\section{Rise in Water Level}

In the absence of structures, no wells were full of water for so many years. It was found that there was sudden rise in water level as soon as the construction of water conservation structures.

The surface runoff in the stream was checked due to the construction of gully plugs, earthen bunds, farm pond etc. Observations were taken at the end of month oct.2012. Figures 4 and 5 show the water levels in the farm ponds immediately after construction and at the end of the month in October 2011, respectively. Increase in the ground water table in the watershed area is one of the important measurable indicators for the success of the watershed development.

\section{Success of Watershed Management Project}

Before construction of recharge structures, water was available for farming only until the end of January. The farmers could take only Kharif crops. But due to the construction of soil and water conservation structures almost $90 \%$ water level is increased. The farmer had already taken rice on his farm, then he grew jowar for which he could take water from the farm pond. The well existing on the downstream side of the plot had shown water availability up to the month of April. Thus, the water was easily available for farming before the next monsoon starts.

\section{Effectiveness of Watershed Management Techniques}

It was found that land had slope from $2 \%$ to $10 \%$. The structures were constructed in the area measuring 0.25 ha. The structures were constructed in the month of May 2012 which included farm pond, gully plugs and contour trenching. The main crop production from this farm was Rice and Groundnut. The intercropping pattern was suggested as Groundnut and Jawar in proportion with 1:1 and Corn and Tur in proportion with 2:1 for Kharif season. Also for rabbi season, it was recommended to have Jawar as sole crop. Details are given in Table 4. 
Table 4. Crop Production - Before and After Watershed Management

\begin{tabular}{lrrrr}
\hline Crops & \multicolumn{2}{c}{ Before Watershed Management } & \multicolumn{2}{c}{ After watershed Management } \\
\cline { 2 - 6 } & Quantity (quintal) & Market rate (Rs./quintal) & Quantity (quintal) & Market rate (Rs./quintal) \\
\hline Jowar & 3.75 & 2500 & 6.50 & 2750 \\
\hline Corn & - & - & 2.00 & 1400 \\
\hline Tur & - & - & 1.50 & 4000 \\
\hline Rice & 4.50 & 4750 & 3.50 & 4850 \\
\hline Groundnut & 6.75 & 5200 & 7.25 & 5800 \\
\hline Total yield & 15.00 & - & 20.75 & - \\
\hline
\end{tabular}

Table 5. Output of the simulations and their comparative statements

\begin{tabular}{cccccccc}
\hline Year & Simulation & Q surf & Q gw & Perc & Wat.YLD & Sed.YLD & Prec. \\
\hline \multirow{3}{*}{2012} & BASE & 56.05 & 122.70 & 157.46 & 191.91 & 9.16 & 582.2 \\
\cline { 2 - 9 } & SIM1 & 56.54 & 122.26 & 157.04 & 183.80 & 8.02 & 582.2 \\
\cline { 2 - 9 } & SIM2 & 52.62 & 126.59 & 160.70 & 188.05 & 7.96 & 582.2 \\
\hline \multirow{3}{*}{2013} & BASE & 141.81 & 244.50 & 291.93 & 404 & 24.97 & 858.10 \\
\cline { 2 - 9 } & SIM1 & 142.65 & 243.70 & 291.08 & 383.89 & 21.74 & 858.10 \\
\cline { 2 - 9 } & SIM2 & 133.91 & 251.44 & 299.70 & 391.09 & 21.54 & 858.10 \\
\hline
\end{tabular}

\section{RESULTS AND DISCUSSION}

\section{Pilot Study Plot}

For the plot selected for pilot study, it was found that for a small plot of 2 ha due to the construction of watershed management structures.

- Predicted annual water storage was $3060 \mathrm{cum}$ (assuming the farm pond may fill at least four times in a year).

- Change in crop yield was from 15 ton per annum to 20.75 ton per annum after watershed management implementation.

- The income per annum of the pilot plot owner, had increased by Rs. 19850/(30.14\%) for the first year immediately after implementation of the structures.

Thus, if every farmer will use the techniques of watershed development for their farms as per the topographical conditions, there will certainly be increase in their farm produce.

\section{Simulation by SWAT Iteration}

SWAT model was run for 3 years i.e. from 2011 to 2013. The year 2011 was used as a warm up year. The output for two simulations including base scenario was tabulated. The results of the simulation were compiled for interpretation of the impact of watershed management structures on flow and sediment yield. Initially, in the base scenario, the sediment loading was $17.065 \mathrm{ton} / \mathrm{ha} /$ year and surface runoff was $98.93 \mathrm{~mm}$. The percolation was found to be $27.04 \%$ of the total precipitation and groundwater contribution was $20.99 \%$. Table 5 shows the output of the simulations in different scenarios and their comparative statements.

The first simulation was carried out with the farm ponds in sub-basin no.1 and 28 along with contouring, terracing and gully plugs in sub-basin 28. This simulation was carried out to correlate the results with the pilot study where the experimental plots were situated in the same sub-basins. Percolation out of the soil, groundwater recharge and surface runoff did not show any remarkable change, but sediment loading was decreased by $12.80 \%$ showing satisfactory impact.

In second simulation, each sub basin was provided with the pond and the impact was studied. The simulation showed $6.34 \%$ decrease in surface runoff, $2.53 \%$ increase in Ground water recharge, $2.74 \%$ increase in percolation and $0.87 \%$ decrease in sediment loading.

In simulation 1, farm ponds were proposed in only two sub-basins whereas, in third simulations, the farm ponds were proposed in all sub-basins. From the results, it is found that in second simulation percentage decrease in sediment loading $(12.80 \%)$ was very much higher than that $(0.87 \%)$ in third simulation. This is because subbasin 1 and sub-basin 28 (which were used in the pilot study) are the most vulnerable sub-basins as per the soil loss is concerned. Both sub-basins are situated at Foothill, carrying a lot of sediment from the hilly terrain above.

Figure 6 shows the graph of overall impact due to all scenarios. The impact corresponding to change in scenario is explained in Table 6.

Similarly, in sub-basin 28 , the other simple watershed management techniques as contouring, gulley plugging and terracing also have been proposed (same as in pilot plot), due to which the sediment entering the farm pond gets checked completely on its upstream side. This reveals that not only the pond alone serves the purpose of soil conservation, but it also needs the provision of other appropriate structures according to the topography of the 


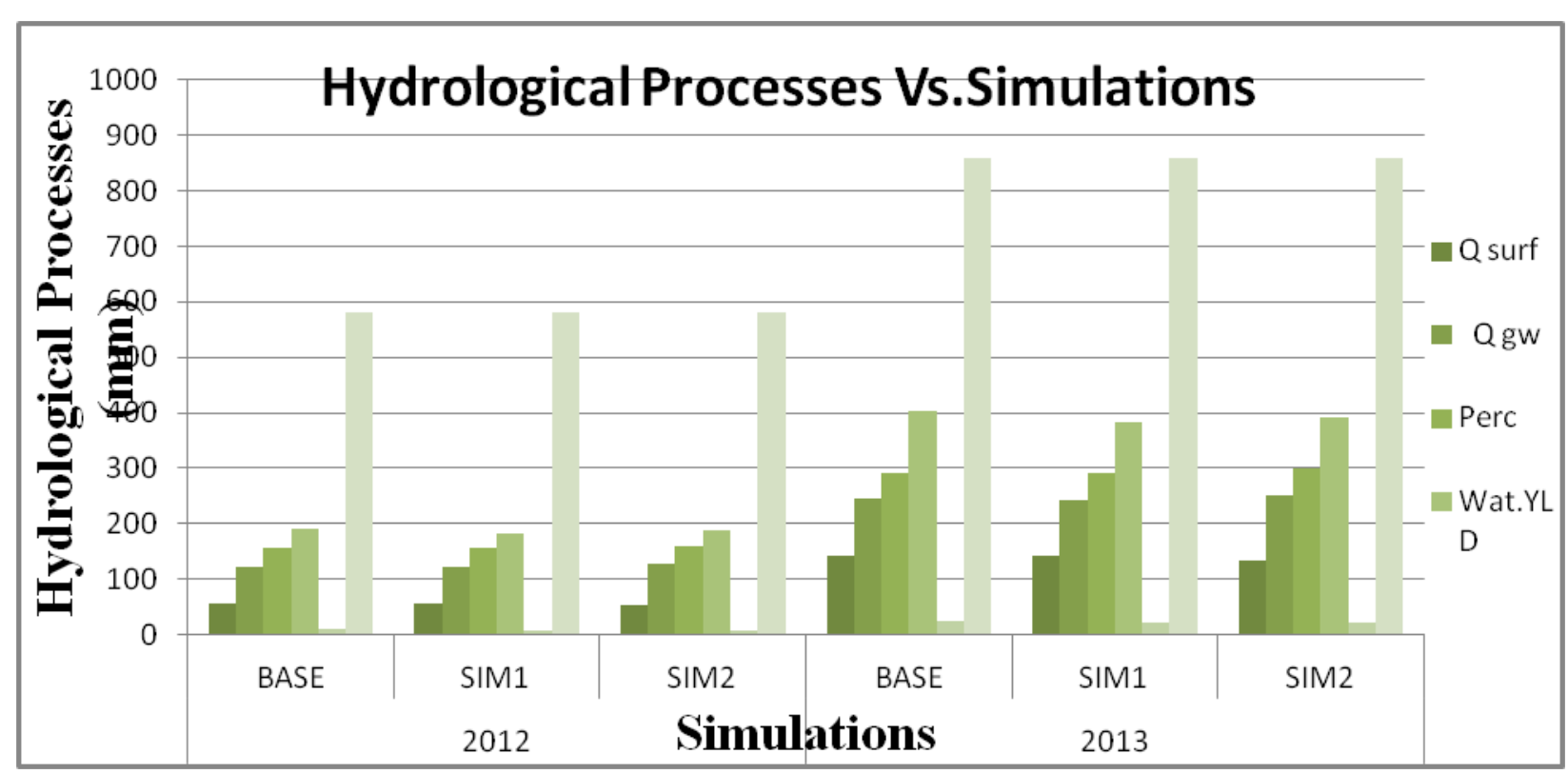

Figure 6. Graph showing overall impact due to all scenarios

Table 6. Impact of Parameter Changes on Hydrological Processes

\begin{tabular}{ccll}
\hline Sr. No. Simulation & Change in Scenario & Impact \\
\hline \multirow{2}{*}{1} & Base Scenario & Original parameters & $\begin{array}{l}\text { Surface Runoff }=144.44 \mathrm{~mm} \\
\text { Ground water recharge }=256.51 \mathrm{~mm} \\
\text { Sediment Yield }=21.54 \mathrm{~T} / \mathrm{Ha} / \mathrm{Year}\end{array}$ \\
\hline \multirow{2}{*}{2} & \multirow{2}{*}{ Simulation 1 1} & $\begin{array}{l}\text { Pilot plot scenario (Farm ponds in sub basin 1 } 1 \\
\text { and subbasin 28 with appropriate BMPs) }\end{array}$ & $\begin{array}{l}\text { Only change in sediment yield. } \\
12.80 \% \text { decrease in sediment yield }\end{array}$ \\
\hline \multirow{2}{*}{3} & \multirow{2}{*}{ Simulation 2 } & Provision of farm ponds in all sub basins & $\begin{array}{l}6.34 \% \text { decrease in surface runoff } \\
2.53 \% \text { increase in ground water recharge, } 0.87 \% \text { decrease in } \\
\text { sediment yield }\end{array}$ \\
\hline
\end{tabular}

terrain on the upstream side of the pond. The provision of one farm pond in each sub-basin of the watershed proved to give good results. For each sub-basin, at least one farmer may get ready to construct the farm pond as it is easy and fast in construction.

\section{CONCLUSION}

In the present research, an area with hilly terrain and high-intensity rainfall had been selected for its watershed management. The pilot plot selected for experimentation had shown expected results revealing the better need of watershed management for such areas as well as it had given better results of soil and water conservation showing the gain in farm yield. From different scenarios tried in model simulations also, it was found that the provision of very simple techniques like contouring, terracing, gulley plugging along with farm ponds being very easy to implement with absolutely no material cost would be the best management practices for soil and water conservation. The simulation with the provision of farm ponds in all the sub-basins proved to be satisfactory for soil conservation.

By implementation in the pilot plot, the farm pond along with appropriate structures on its upstream side for checking soil loss proved to be effective for controlling soil erosion and a sustainable development option in the watershed. This reveals that not only the pond alone serves the purpose of soil conservation, but it also needs the provision of other appropriate structures according to the topography of the terrain on the upstream side of the pond. In SWAT simulation also, the farm ponds provided with the appropriate structures on their upstream side proved the better solutions. Its implementation is also fast and cost-effective with the help of local labors.

SWAT model proved to be the effective tool in computing the impact of changes in land management and climate on runoff and sediment yield. Thus, it is concluded that a physically-based SWAT model can be used not only to find the critical areas but also to determine the capabilities of the model to finalize the best watershed management practices. If implemented on a field scale, the SWAT model can be used in future, as a guide for the farmers at an individual level for finalization of the best management practices for soil and water conservation for their farms. 


\section{REFERENCES}

Das, G. (2004). Hydrology and Soil Conservation Engineering. Published by Prentice Hall of India (P) Ltd. New Delhi, India.

Garg, K. K. and Wani, S. P. (2011). Hydrological modeling of a micro watershed using GIS based model SWAT: A Case Study of Kothapally watershed in SouthernIndia. Proceedings of National Symposium, on "Use of High Science Tools in Integrated watershed management", New Delhi, India.

Ingavale, R. R., Jadhav, V. V. and Raut, P. D. (2013). Studies on watershed Management in Shivaji University, Kolhapur, India. International Research Journal of Environmental Sciences, 7, 35-38.

Jothiprakash, V., Mohan S. and Elango, K. (1997). Influence of percolation ponds-A recharging structure in a small watershed. Proceedings of National Conference on Ground Water Sources at JNTU Hyderabad, 280-289.

Naik, A. V. (2009). Watershed Management: A Way to sustainable development. CAB Calling Newsletter, JulySept. 2009.

Kakade, B. K. (2012). Integrated watershed Development Program: Baif Experience. Technical Report.

Krause, P. D., Boyle, P. and Base, F. (2005). Comparison of different efficiency criteria for hydrological model assessment. Adv. Geosci., 5, 89-97. https://doi.org/10.5194/adgeo-5-89-2005

Kumbhar, S. (2011). Watershed Development Plan for Kaneri Watershed. M. E. Thesis, Rajarambapu Institute of Technology, Sakharale. https://doi.org/10.9790/1684-0660714

Kumbhar, V., Swami, V. and Kulkarni, S. (2013). Effectiveness of watershed management: A means of economic development: A case study. Journal of Mechanical and Civil Engineering, 6(6), 7-14.

Mehta, A. and Trishna, S. (2008). Escaping poverty: The Relegan Siddhi Case. Chronic Poverty research centre, Working Paper No. 119. https:// doi.org/10.2139/ssrn.1538891

Mishra, B. (1996). A successful case of participatory watershed management at Ralegan Siddhi Village in District Ahmednagar, Maharashtra, India. FAO Corporate Document Repository.

Monteith, J. L. (1965). Evaporation and Environment. In The state and movement of water in living organism. 19th Symp. Soc. Exptl. Biol. pp. 205-234.

Moriasi, D. N., Arnold, J. G., Gassman, P. W., Abbaspour, K. C., White, M. J., Srinivasan, R., Santhi, C., Harmel, R. D., Van Griensven, A., Van Liew, M. W., Kannan, N. and Jha, M. K. (2012). SWAT Model use: Calibration and Validation. Transactions of the ASABE, 55(4), 1491-1508. https://doi.org/10.13031/2013.42265

Reddy K. S., Kumar, M., Rao, K. V., Maruthi, V., Reddy, B. M. K., Umesh, B., Ganesh Babu, G., Srinivasa Reddy, K., Vijayalaxmi and Venkateswaralu, B. (2012). Farm Ponds a Climate resilient technology for rainfed agriculture planning, design and construction. Farm Ponds Technical Bulletin 2012.

Ridwansyah, I., Pawitan, H., Sinukaban, N. and Yayat, H. (2014). Watershed Modeling with Arc SWAT and SUFI 2 in Cisadane catchment area: Calibration and validation of river flow prediction. International Journal of Science and Engineering, 6(2), 92-101. https:// doi.org/10.12777/ijse.6.2.92-101

Sathian, K. K. and Shyamala, P. (2009). Application of GIS integrated SWAT model for basin level water balance. Indian Journal of Soil Conservation, 37, 100-105.

Swami, V. and Kulkarni, S. (2011). Watershed Management: A means of sustainable development: A case study. International Journal of Engineering Science and Technology, 3(3), 2105-2112. 